\title{
THE EFFECT OF CELLULAR ORGANIC MATTER PRODUCED BY CYANOBACTERIA MICROCYSTIS AERUGINOSA ON WATER PURIFICATION
}

\author{
MARTIN PIVOKONSKÝ, LENKA PIVOKONSKÁ, \\ JITKA BÄUMELTOVÁ, PETRA BUBÁKOVÁ
}

Institute of Hydrodynamics AS CR, v. v. i., Pod Patankou 5, 16612 Prague 6, Czech Republic; mailto: pivo@ih.cas.cz

\begin{abstract}
The aim of this paper is to investigate the influence of COM (Cellular Organic Matter) produced by Microcystis aeruginosa on the process of water purification by destabilisation and subsequent aggregation of the impurity particles. The research was carried out with a raw water into which COM was added. The removal efficiency of the most significant components of COM, i.e. polysaccharides and proteins, was investigated. It was found that the removal efficiency of polysaccharides and proteins was dependent on the reaction conditions $(\mathrm{pH}$, type of destabilisation reagent and its dosage). The removal efficiency of COM was relatively low. It was about $46 \%$ and $41 \%$ using ferric sulphate and aluminium sulphate aggregation, respectively. In comparison to the other organic components of COM, mainly polysaccharides, the proteins are removed with a higher efficiency. The GPC analyses of the residual COM showed that the proteins of higher molecular weight were aggregated with a higher efficiency.
\end{abstract}

KEY WORDS: AOM (Algal Organic Matter), COM (Cellular Organic Matter), Destabilisation, Aggregation, Reaction Conditions, Water Purification.

Martin Pivokonský, Lenka Pivokonská, Jitka Bäumeltová, Petra Bubáková: VLIV BUNĚČNÝCH ORGANICKÝCH LÁTEK PRODUKOVANÝCH SINICÍ MICROCYSTIS AERUGINOSA NA ÚPRAVU VODY. J. Hydrol. Hydromech., 57, 2009, 2; 23 lit., 9 obr., 1 tab.

Cílem práce je opis vlivu buněčných organických látek (COM) produkovaných sinicí Microcystis aeruginosa na proces úpravy vody pomocí destabilizace a následné agregace znečištujuících příměsí. Výzkum byl uskutečňován se syntetickou surovou vodou, do které byly přidány COM získané laboratorní kultivací $M$. aeruginosa. V průběhu laboratorních testů byla sledována především účinnost odstranění dvou základních složek COM, tj. polysacharidů a proteinů. Bylo zjištěno, že tato účinnost závisí především na reakčních podmínkách (typu a dávce destabilizačního činidla a pH). Účinnost odstranění COM byla poměrně nízká, maximální dosažená účinnost byla $46 \%$ při destabilizaci pomocí síranu železitého a $41 \%$ při použití síranu hlinitého. Bylo zjištěno, že s vyšší účinností jsou odstraňovány proteiny, obzvláště pak proteiny s vyšší molekulovou hmotností.

KLÍČOVÁ SLOVA: organické látky produkované fytoplanktonem, buněčné organické látky, destabilizace, agregace, reakční podmínky, úprava vody.

\section{Introduction}

Effective removal of natural organic matter (NOM) and especially that produced by a vast development of phytoplankton (Algal Organic Matter $-\mathrm{AOM}$ ) is one of the very significant challenges of the purification of the surface waters (Bernhardt et al., 1985, 1986, 1989; Hoyer et al., 1987; Takaara et al., 2005, 2007; Pivokonsky et al., 2006). Generally, these organic matters can be distinguished into the substances that are released by metabolic activity of micro-organisms - the extracellular organic matter (EOM) and the substances released during the process of their decay - the intracellular organic matter (COM) (Pivokonsky et al., 2006; Lüsse et al., 1985; Hoyer et al., 1985). The COM represents a specific problem due to the occasional sudden increase in its concentration.

A great attention was given to the influence of AOM on the purification of water polluted with different impurities such as aluminosilicates, humic matter, etc. Various studies showed that the influence of EOM on the process of destabilisation and aggregation of the impurity particles could be com- 
pared to that of non-ionic polymers (Bernhardt et al., 1985, 1986, 1989; Hoyer et al., 1987). At their low concentrations the efficiency of water purification increases due to the formation of inter-particle bridges between the impurity particles or adsorption to their surfaces. In contrast, at higher concentrations the AOM inhibits the process of destabilisation of the impurity particles by increasing negative charge on their surface. Furthermore, certain substances contained in AOM, primarily proteins, also inhibit the destabilisation process. It is assumed that this results from the formation of higher-valence cation complexes and hydrated ions aided by coordination bonds. The formation of these complexes results in increased consumption of destabilisation reagent and decreasing efficiency of the destabilisation process (Bernhardt et al., 1989). The extent of the inhibition effect of the $\mathrm{AOM}$ is dependent upon its composition which is influenced by the kind of organisms and their growth phase (Pivokonsky et al., 2006). The COM are the substances most difficult to remove from the water. The reason is that these organic compounds are released suddenly in large quantities during decay of phytoplankton. Another very important reason is different chemical composition of COM in comparison to the other NOM and EOM ( $\mathrm{Ta}$ kaara et al., 2005, 2007; Pivokonsky et al., 2006).

The influence of AOM on the destabilisation and aggregation efficiency is not yet adequately explained. The contribution of authors to this theme is presented in this paper. The results obtained by investigating the effect of COM pollution produced by $M$. aeruginosa on its removal efficiency by coagulation with ferric sulphate and aluminium sulphate purification are summarised in this paper.

\section{Material and methods}

\section{1 Cyanobacteria cultivation procedure}

The cyanobacteria Microcystis aeruginosa KUTZ. (ZAPOMELOVA 2006/2) was used in this study. Inoculums of this strain were kindly supplied by the Culture Collection of Algal Laboratory, Institute of Botany, AS CR, v. v. i., Czech Republic. The laboratory strain $M$. aeruginosa was grown in a 201 volume of $\mathrm{Z}$ medium $(\mathrm{pH}=8.5)($ Strub and Schweiz, 1961) at $24{ }^{\circ} \mathrm{C}$ and regularly shaken by a shaking apparatus operating at $40 \mathrm{rpm}$. The 16hlight/8h-dark cycle was applied. The cultures were illuminated using four $40 \mathrm{~W}$ cool-white fluorescent lamps supplying about 6000 lux. All materials and media were sterilized by autoclaving before assembly and operation. The growth of $M$. aeruginosa was monitored by chlorophyll-a in the culture. Cyanobacterial cells were harvested on $16^{\text {th }}$ day of the cultivation period in the steady-state growth (dominant number of cells was free).

\section{2 COM preparation procedure}

The COM samples were prepared by destruction of the microorganism's cells which were separated from the growth media (2 1 samples) on a $0.22 \mu \mathrm{m}$ membrane filter (Millipore, USA) on the $16^{\text {th }}$ day of the cultivation time (the steady-state growth). The separated cells were mixed with ultrapure water $(200 \mathrm{ml})$. The destruction of cells was performed using an ultrasonic homogenizer (HD 3200, 20 $\mathrm{kHz}, 60 \mathrm{~W}$ ), which was dipped into the beaker containing the separated cells of microorganisms. The efficiency of cells destruction was checked in an optical microscope (Optech B4T, Olympus, Japan). The residual solids (cells) were removed on a 0.22 $\mu \mathrm{m}$ membrane filter, and the filtrates concentrated ten-times in a rotary evaporator (Laborota 4000 $\mathrm{HB} / \mathrm{G} 1$, Heidolph, Germany) at $30^{\circ} \mathrm{C}$. The concentrated $\mathrm{COM}$ was stored at $-18^{\circ} \mathrm{C}$.

\section{3 COM characterisation procedure Determination of protein portion from the COM}

The COM consists primarily of carbohydrates and proteins. Therefore, portions of proteins $\left(\mathrm{DOC}_{\mathrm{P}}\right)$ and non-protein (carbohydrates) substances $\left(\mathrm{DOC}_{\mathrm{NP}}\right)$ were measured during the experiments. Proteins were isolated from the COM using $\mathrm{H}_{2} \mathrm{WO}_{4}$ as a protein precipitant (Dawson et al., 1986). The protein precipitate was then separated from the dissolved organic matter by filtration through a $0.22 \mu \mathrm{m}$ membrane filters (MF, Millipore, USA) and $\mathrm{DOC}_{\mathrm{NP}}$ was analysed in the filtrate. The protein portion $\mathrm{DOC}_{\mathrm{P}}$ is calculated as follows:

$\mathrm{DOC}_{\mathrm{P}}=\mathrm{DOC}_{\mathrm{T}}-\mathrm{DOC}_{\mathrm{NP}}$,

where $\mathrm{DOC}_{\mathrm{T}}$ is the total DOC of the COM.

The protein precipitations were carried out in triplicate and errors of $\mathrm{DOC}_{\mathrm{P}}$ were less than $5 \%$. The methodology of determination of protein portion from the COM can be found in Dawson et al. (1986) and Pivokonsky et al. (2006). 


\section{DOC analysis}

A Shimadzu TOC- $\mathrm{V}_{\mathrm{CPH}}$ analyzer was used for organic carbon analysis. Dissolved organic carbon (DOC) was calculated as the difference between the total carbon and inorganic carbon measurements for samples filtered through $0.22 \mu \mathrm{m}$ membrane filter (MF, Millipore). All measurements were conducted in triplicate and errors were less than $2 \%$.

\section{Molecular weight fractionation}

The aqueous COM samples were dialyzed against $0.05 \mathrm{M}$ phosphate buffer $(\mathrm{pH}$ 7.0) using dialysis membrane (Amersham Bioscience Corp., MW cut off: $10 \mathrm{kDa}$ ). The dialyzed samples were applied to the gel permeation chromatography (GPC) for the apparent molecular weight fractionation. The $\mathrm{DOC}_{\mathrm{T}}$ concentration of all the COM samples was $100 \mathrm{mg} \mathrm{l}^{-1}$ to eliminate potential concentration effects on GPC. The MW fractionation was performed by HPLC system (Agilent 1100 series, Agilent Technologies) with diode array detector (DAD). The Zorbax GF-250 (9.4 mm x $250 \mathrm{~mm}, 4$ $\mu \mathrm{m})$ and GF-450 columns $(9.4 \mathrm{~mm} \times 250 \mathrm{~mm}, 6$ $\mu \mathrm{m})$ were used for the GPC. The separation range applied was 4,000-900,000 for globular proteins using GF-250 and GF-450 columns in series. The buffer used for MW fractionation was $0.05 \mathrm{M}$ phosphate buffer $(\mathrm{pH} 7.0)$. The flow rate of mobile phase was $2.00 \mathrm{ml} \mathrm{min}^{-1}$ at the temperature of $23^{\circ} \mathrm{C}$. The sample volume was $20 \mu \mathrm{l}$. The maximum absorption wavelength $\left(\lambda_{\max }=280 \mathrm{~nm}\right)$ was used for measurement of MW of the COM samples. The wavelength of $280 \mathrm{~nm}$ was used especially for the protein detection. Data analysis was performed using Agilent Technologies Chemstation software. The system was calibrated using the following gel filtration standards (Sigma-Aldrich Co.): cyanocobalamin $(1.35 \mathrm{kDa})$, ribonuclease-a $(13.7 \mathrm{kDa})$, myoglobin $(17 \mathrm{kDa})$, carbonic anhydrase $(29 \mathrm{kDa})$, albumin $(66 \mathrm{kDa})$, alcohol dehydrogenase (150 $\mathrm{kD}), \beta$-amylase $(200 \mathrm{kDa})$, apoferritin $(443 \mathrm{kDa})$, thyroglobulin $(669 \mathrm{kDa})$ and imunoglobulin $(900$ $\mathrm{kDa}$ ). A calibration curve was based on a linear relationship between the retention time and the actual $\log$ MW. In all cases, a good linear correlation between the retention time and $\log$ MW was observed for the calibration curves $\left(\mathrm{R}^{2}=0.996\right)$. BioRad gel filtration standards of bovine gamma globulin (158 kDa) and chicken ovalbumin (44 $\mathrm{kDa}$ ) were used as control samples. Standard error was $\pm 1.05 \mathrm{kDa}$ for gamma globulin and \pm 0.62 for chicken ovalbumin. Reproducibility of the MW fractionation of COM samples was very good, with MW deviations of less than 3\% from repeated measurements.

\subsection{Coagulation procedure Water}

The ultrapure water with added $\mathrm{NaHCO}_{3}$ was used in these experiments. The COM of a concentration $\mathrm{DOC}_{\mathrm{T}}=7.0 \mathrm{mg} \mathrm{l}^{-1}$ was prepared. Other relevant water quality parameters were: $\mathrm{pH}=8.3$, $\mathrm{KNK}_{4.5}=1.99 \mathrm{mmol} \mathrm{l}^{-1}, \mathrm{Fe}=0.007 \mathrm{mg} \mathrm{l}^{-1}, \mathrm{Al}=$ $=0.004 \mathrm{mg} \mathrm{l}^{-1}$.

\section{Jar tests}

The COM removal during water purification was investigated by jar tests. The LMK 8 (Institute of Hydrodynamics, AS CR, v. v. i., Czech Republic) variable speed eight station flocculator with a paddle type stirrer housing standard 21 beakers fitted with a variable speed drive and equipped with an infinite speed controller and revolution counter was used for jar tests. The tested volume of water in the beakers was $1.5 \mathrm{l}$. Ferric sulphate and aluminium sulphate were applied as destabilising reagents (coagulants). The procedure consisted of a 1 minute of homogenization agitation $\left(\bar{G}=200 \mathrm{~s}^{-1}\right), 15$ minutes of aggregation agitation $\left(\bar{G}=70 \mathrm{~s}^{-1}\right)$ and 60 minutes of settling.

The effect of coagulation was ascertained by:

(i) direct comparison of water quality indicators: content of cation of destabilising reagent (concentration of $\mathrm{Fe} / \mathrm{c}_{\mathrm{Fe}} /$ and $\mathrm{Al} / \mathrm{c}_{\mathrm{Al}} /$ ), dissolved organic carbon DOC, $\mathrm{pH}$ value and alkalinity $\left(\mathrm{ANC}_{4.5}\right)$. Methodology of chemical analyses is in details described in Polasek and Mutl, 1995.

(ii) determination of the degree of aggregation $\alpha$, calculated according to the relationship

$\alpha_{A}=\frac{C_{0}-C_{F}}{C_{0}}$,

where $C_{0}$ is the concentration of indicator monitored (Al, Fe, DOC) at the point of testing and $C_{F}$ is the concentration of the same indicator determined in the centrate of the sample $C_{0}$ after its treatment by centrifugation under defined conditions (3000 rpm, T $=20 \mathrm{~min}$ ) (Hereit et al., 1980; Polasek and Mutl, 1995). 
(iii) determination of the test of aggregation, which enables the aggregates formed to be ascribed to one of the four basic size-categories, namely: nonaggregated particles $(N A)$, primary aggregates $(P R)$, micro-aggregataes $(M I)$ and macroaggregates $(M A)$. The technologically significant categories of particles are determined according to the following relationships:

$$
\begin{aligned}
& M A=\frac{C_{0}-C_{5}}{C_{0}}, M I=\frac{C_{5}-C_{60}}{C_{0}}, P R=\frac{C_{60}-C_{60 F}}{C_{0}}, \\
& N A=\frac{C_{60 F}}{C_{0}},
\end{aligned}
$$

and

$M A+M I+P R+N A=1$,

where $C_{0}, C_{5}$ and $C_{60}$ - the concentrations of the monitored determinant measured in the samples taken at the beginning of sedimentation, after 5 , and 60 minutes of sedimentation and $C_{60 F}-$ a concentration of the monitored determinant measured in concentrate of the $C_{60}$ sample after its treatment by centrifugation under defined conditions $(3000 \mathrm{rpm}$, $\mathrm{T}=20 \mathrm{~min}$ ) (Hereit et al., 1980; Polasek and Mutl, 1995).

\section{Results and discussion}

The results of COM characterisation show that the COM of M. aeruginosa is composed of protein and non-protein organic matters. The protein portion determined as $\mathrm{DOC}_{\mathrm{P}}$ was measured to be about $59.9 \%$ of $\mathrm{DOC}_{\mathrm{T}}$ in the $\mathrm{COM}$ and the non-protein organic is the balance of $40.1 \%$. The proteins characterized by $21,85,234,359,470 \mathrm{kDa}$ and more than $900 \mathrm{kDa}$ were identified in the $M$. aeruginosa COM (Fig. 1). The protein concentration in the raw water was $\mathrm{DOC}_{\mathrm{P}}=4.12 \mathrm{mg} \mathrm{l}^{-1}$ and non-protein concentration was $\mathrm{DOC}_{\mathrm{NP}}=2.86 \mathrm{mg}^{-1}$. The character of the COM produced by cyanobacteria $M$. aeruginosa and other cyanobacteria and green algae are discussed in sufficient details in literature (Pivokonsky et al., 2006).

The dependence of removal of the COM produced by $M$. aeruginosa on dosage of destabilisation reagent is shown in Figs. 2 and 3. It is evident that residual concentration of total organic matter $\left(\mathrm{DOC}_{\mathrm{T}}\right)$ drops up to a dosage of $0.160 \mathrm{mmol} \mathrm{l}^{-1}$ (90 $\left.\mathrm{mg} \mathrm{l}^{-1}\right)$ with ferric sulphate and $0.105 \mathrm{mmol} \mathrm{l}^{-1}(70$ $\mathrm{mg} \mathrm{l}^{-1}$ ) with aluminium sulphate aggregation. Thereafter residual concentrations of $\mathrm{DOC}_{\mathrm{T}}$ remain virtually unchanged. The aggregation efficiency of organic matter is relatively low and reaches its highest value of about $\alpha \mathrm{DOC}_{\mathrm{T}}=0.45$ with ferric sulphate and $\alpha \mathrm{DOC}_{\mathrm{T}}=0.41$ with aluminium sulphate (Figs. 4 and 5). Maximum aggregation efficiency is attained in the range of high dosage of destabilisation reagent when a considerable $\mathrm{Fe}$ and Al concentrations remain non-aggregated (Figs. 2 and 3).

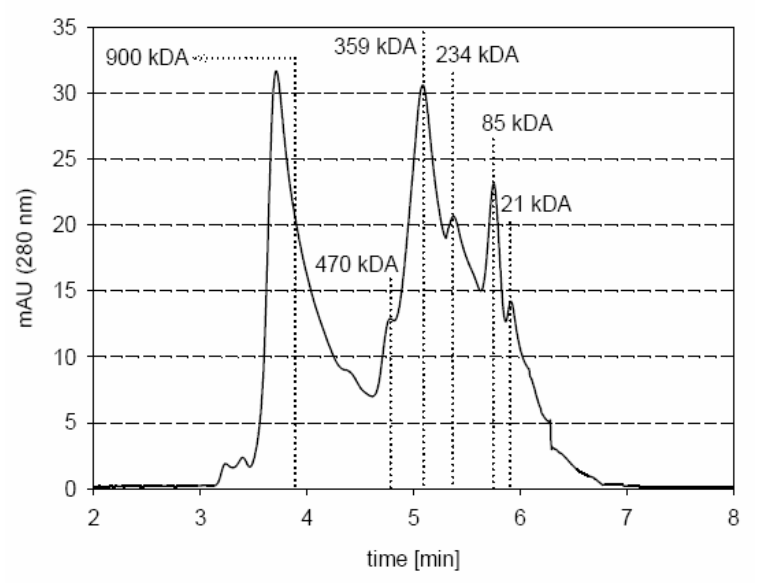

Fig. 1. GPC profile for the COM in raw water.

Obr. 1. GPC profil COM v surové vodě.

In contrast to the curves of residual concentration of organic matter $\left(\mathrm{DOC}_{\mathrm{T}}\right)$, the concentration curves of residual $\mathrm{Fe}$ and $\mathrm{Al}$ have a quite distinct optimum $\left(\mathrm{c}_{\mathrm{Fe}}=0.12 \mathrm{mg} \mathrm{l}^{-1}, \mathrm{c}_{\mathrm{Al}}=0.16 \mathrm{mg}^{-1}\right)$ as shown in Figs. 2 and 3. The residual $\mathrm{Fe}$ reaches its maximum $\mathrm{c}_{\mathrm{Fe}}=1.23 \mathrm{mg} \mathrm{l}^{-1}$ at a dosage around $0.018 \mathrm{mmol} \mathrm{l}^{-1}$ $\left(10 \mathrm{mg} \mathrm{l}^{-1}\right) \mathrm{Fe}_{2}\left(\mathrm{SO}_{4}\right)_{3} 9 \mathrm{H}_{2} \mathrm{O}$ and $\mathrm{pH}=7.56$. With a further increase in dosage, the residual Fe gradually decreases up to its minimum $\mathrm{c}_{\mathrm{Fe}}=0.12 \mathrm{mg} \mathrm{l}^{-1}$ at a dosage of $0.125 \mathrm{mmol} \mathrm{l}^{-1}\left(70 \mathrm{mg} \mathrm{l}^{-1}\right)$ and $\mathrm{pH}=6.33$. A further increase in ferric sulphate dosage results in another sharp increase in residual $\mathrm{Fe}$ up to $\mathrm{c}_{\mathrm{Fe}}=$ $=1.91 \mathrm{mg} \mathrm{l}^{-1}$ which is reached at a dosage of 0.178 $\mathrm{mmol} \mathrm{l}^{-1}\left(100 \mathrm{mg} \mathrm{l}^{-1}\right)$ and $\mathrm{pH}=5.43$ and thereafter increases gradually until alkalinity of the water was fully utilised (Fig. 2) at a dosage of about 0.231 $\mathrm{mmol} \mathrm{l}^{-1}\left(130 \mathrm{mg} \mathrm{l}^{-1}\right)$.

The residual $\mathrm{Al}$ reaches its maximum $\mathrm{c}_{\mathrm{Al}}=1.29$ $\mathrm{mg} \mathrm{l}^{-1}$ at a dosage around $0.030 \mathrm{mmol} \mathrm{l}^{-1}\left(20 \mathrm{mg} \mathrm{l}^{-1}\right)$ $\mathrm{Al}_{2}\left(\mathrm{SO}_{4}\right)_{3} \quad 18 \mathrm{H}_{2} \mathrm{O}$ and $\mathrm{pH}=7.58$ (Fig. 3). After reaching this maximum, residual $\mathrm{Al}$ gradually decreases to its lowest value $\mathrm{c}_{\mathrm{Al}}=0.16 \mathrm{mg} \mathrm{l}^{-1}$ which is attained at a dosage of $0.075 \mathrm{mmol} \mathrm{l}^{-1}\left(50 \mathrm{mg} \mathrm{l}^{-1}\right)$ and $\mathrm{pH}=6.67$. With a further increase in dosage, the residual $\mathrm{Al}$ gradually increases until alkalinity of the water $\left(\mathrm{ANC}_{4.5}\right)$ is fully utilised (Fig. 3) at a dosage of about $0.210 \mathrm{mmol} \mathrm{l}^{-1}\left(140 \mathrm{mg} \mathrm{l}^{-1}\right)$. 


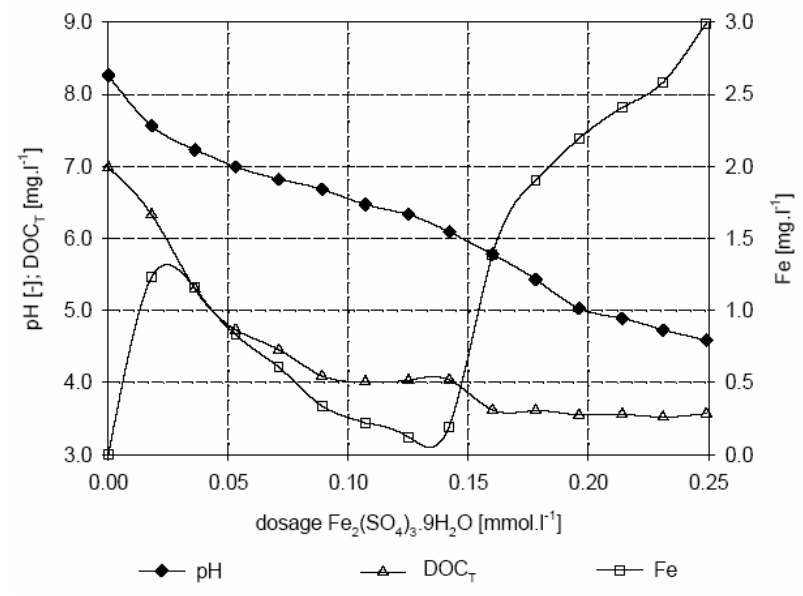

Fig. 2. Dependence of residual $\mathrm{Fe}$ and $\mathrm{DOC}_{\mathrm{T}}$ on ferric sulphate dosage.

Obr. 2. Závislost zbytkového železa a $\mathrm{DOC}_{\mathrm{T}}$ na dávce síranu železitého.

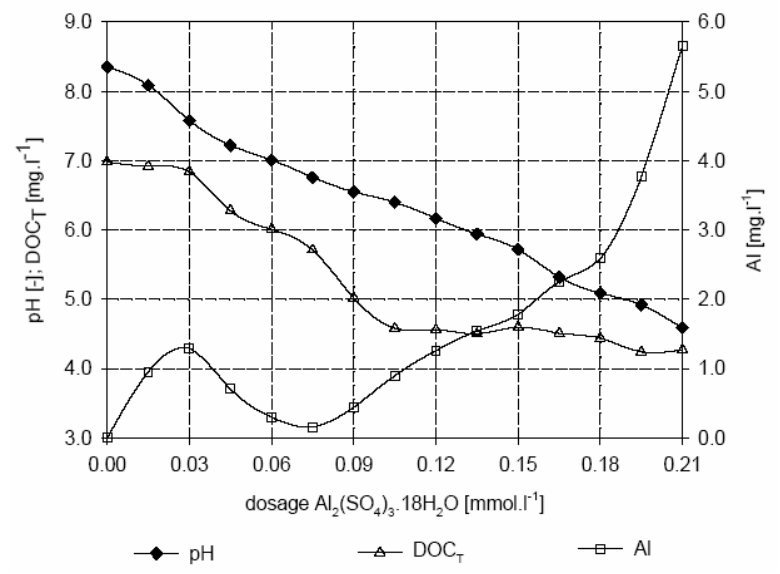

Fig. 3. Dependence of residual $\mathrm{Al}$ and $\mathrm{DOC}_{\mathrm{T}}$ on aluminium sulphate dosage.

Obr. 3. Závislost zbytkového hliníku a $\mathrm{DOC}_{\mathrm{T}}$ na dávce síranu železitého.

The efficiency of Fe-aggregation is about $\alpha_{\mathrm{Fe}}=$ $=0.90$ in a dosage range between 0.071 and $0.178 \mathrm{mmol}^{-1}$ (40 and $100 \mathrm{mg} \mathrm{l}^{-1}$ ). The maximum aggregation efficiency $\alpha_{\mathrm{Fe}}=0.92$ is attained at a dosage of $0.160 \mathrm{mmol} \mathrm{l}^{-1}\left(90 \mathrm{mg} \mathrm{l}^{-1}\right.$ ) (Fig. 4). Similarly, the efficiency of Al-aggregation is about $\alpha_{\mathrm{Al}}$ $=0.90$ also in a dosage range between 0.060 and $0.150 \mathrm{mmol} \mathrm{l}^{-1}$ (40 and $100 \mathrm{mg} \mathrm{l}^{-1}$ ). However, the maximum $\alpha_{\mathrm{Al}}=0.92$ is attained at a dosage of $0.060 \mathrm{mmol} \mathrm{l}^{-1}\left(40 \mathrm{mg} \mathrm{l}^{-1}\right)$ (Fig. 5). Comparison of the residual $\mathrm{Fe}$ and $\mathrm{Al}$ ions shows that the lowest $\mathrm{Fe}$ concentration is attained at a dosage of $0.125 \mathrm{mmol}$ $1^{-1}\left(70 \mathrm{mg} \mathrm{l}^{-1}\right)$ whereas the lowest $\mathrm{Al}$ concentration is attained at a dosage of $0.075 \mathrm{mmol} \mathrm{l}^{-1}\left(50 \mathrm{mg} \mathrm{l}^{-1}\right)$. In contrast to that the lowest residual $\mathrm{DOC}_{\mathrm{T}}=3.6$ $\mathrm{mg} \mathrm{l}^{-1}$ is attained at a dosage of $0.178 \mathrm{mmol}^{-1}(100$ $\mathrm{mg}^{-1}$ ) of ferric sulphate whilst in the case of aluminium sulphate the lowest $\mathrm{DOC}_{\mathrm{T}}=4.2 \mathrm{mg} \mathrm{l}^{-1}$ is attained at a dosage of $0.195 \mathrm{mmol} \mathrm{l}^{-1}\left(130 \mathrm{mg} \mathrm{l}^{-1}\right)$.

It is evident from the results obtained that the efficiency of COM aggregation is dependent on $\mathrm{pH}$ values. It was found that the dissolved organic substances are the most efficiently separated in a $\mathrm{pH}$ ranging between 5.0 and 6.5 and sometimes even at $\mathrm{pH}<5.0$ (Edzwald et al., 1982; Edwards and Amirtharajah, 1985; Polasek and Mutl, 1995, 2005; Gregor et al., 1997; Pivokonska and Pivokonsky, 2007). The $\mathrm{pH}$ value influences also the prevailing type of Fe-hydroxopolymer which is mainly characterized by the magnitude of surface charge. The charge magnitude determines efficiency of a hydroxopolymer as destabilisation reagent (Polasek and Mutl, 1995, 2005).

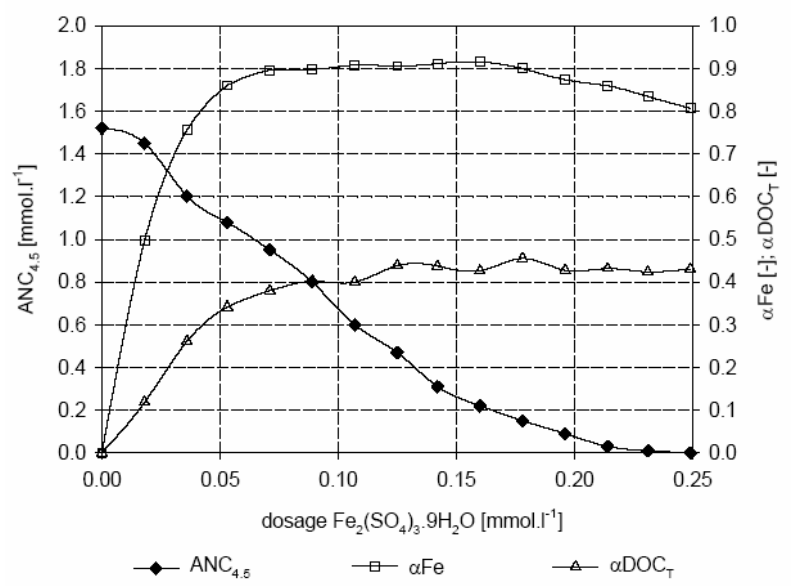

Fig. 4. Dependence of $\alpha \mathrm{Fe}$ and $\alpha \mathrm{DOC}_{\mathrm{T}}$ on ferric sulphate dosage.

Obr. 4. Závislost $\alpha \mathrm{Fe}$ a $\alpha \mathrm{DOC}_{\mathrm{T}}$ na dávce síranu železitého.

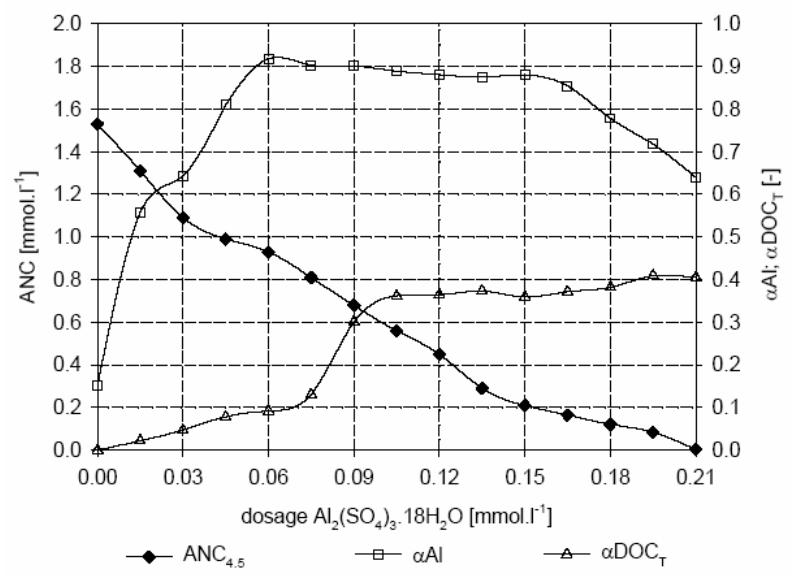

Fig. 5. Dependence of $\alpha \mathrm{Al}$ and $\alpha \mathrm{DOC}_{\mathrm{T}}$ on aluminium sulphate dosage.

Obr. 5. Závislost $\alpha \mathrm{Al}$ a $\alpha \mathrm{DOC}_{\mathrm{T}}$ na dávce síranu hlinitého. 
Figs. 6 and 7 show comparison of the changes in residual protein $\left(\mathrm{DOC}_{\mathrm{P}}\right)$ and non-protein $\left(\mathrm{DOC}_{\mathrm{NP}}\right)$ organic matters with ferric and aluminium sulphate dosages. In the case of ferric sulphate (Fig. 6) $\mathrm{DOC}_{\mathrm{P}}$ gradually decreases with dosage to around $1.5 \mathrm{mg} \mathrm{l}^{-1}$ at a dosage of $0.089 \mathrm{mmol}^{-1}\left(50 \mathrm{mg} \mathrm{l}^{-1}\right)$ and with a further increase in dosage it decreases very slowly to a concentration of $1.07 \mathrm{mg} \mathrm{l}^{-1}$ which is attained at a dosage around $0.160 \mathrm{mmol} \mathrm{l}^{-1}$ (90 $\mathrm{mg}^{-1}$ ) and thereafter it remains unchanged. In contrast, $\mathrm{DOC}_{\mathrm{NP}}$ is reduced by $0.4 \mathrm{mg} \mathrm{l}^{-1}$ at a dosage of $0.018 \mathrm{mmol} \mathrm{l}^{-1}\left(10 \mathrm{mg} \mathrm{l}^{-1}\right)$.

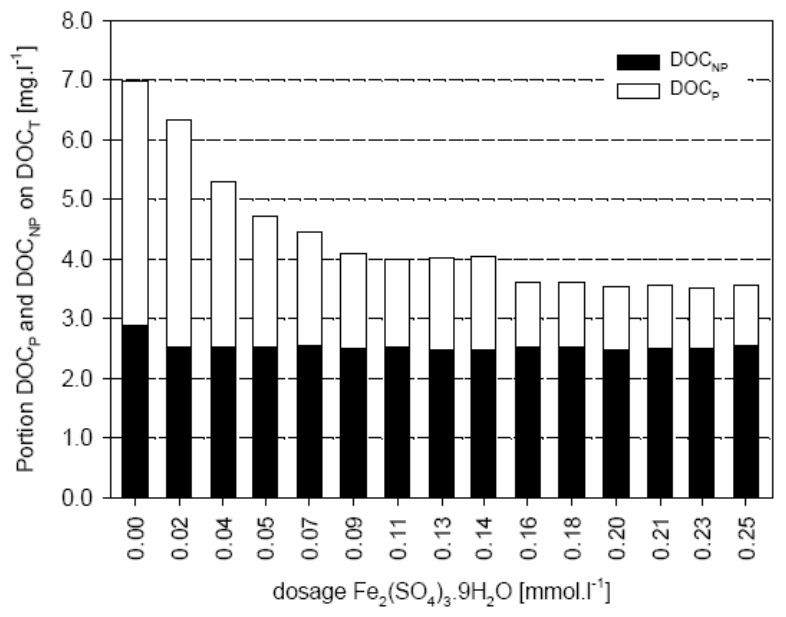

Fig. 6. Dependence of $\mathrm{DOC}_{\mathrm{T}}, \mathrm{DOC}_{\mathrm{NP}}$ and $\mathrm{DOC}_{\mathrm{P}}$ on ferric sulphate dosage.

Obr. 6. Závislost $\mathrm{DOC}_{\mathrm{T}}, \mathrm{DOC}_{\mathrm{NP}}$ a $\mathrm{DOC}_{\mathrm{P}}$ na dávce síranu železitého.

In the case of aluminium sulphate (Fig. 7) $\mathrm{DOC}_{\mathrm{P}}$ gradually decreases up to a dosage of $0.075 \mathrm{mmol}^{-1}$ $\left(50 \mathrm{mg} \mathrm{l}^{-1}\right)$ and then it drops to a value of $2.06 \mathrm{mg} \mathrm{l}^{-1}$ at a dosage of $0.105 \mathrm{mmol} \mathrm{l}^{-1}\left(70 \mathrm{mg} \mathrm{l}^{-1}\right),(\mathrm{pH}=$ $=6.76$ to 6.17 and $\mathrm{ANC}_{4.5}=0.81$ to $0.45 \mathrm{mmol} \mathrm{l}^{-1}$ ). With further increase in dosage $\mathrm{DOC}_{\mathrm{P}}$ remains unchanged. This sudden drop in the residual $\mathrm{DOC}_{\mathrm{P}}$ concentrations indicates the optimum reaction conditions at which this drop is most likely the result of adsorption of these compounds onto the hydrolysis products of destabilisation reagents (Polasek and Mutl, 1995). Similarly, in the case of ferric sulphate, Fig. 6 shows such a sudden improvement in the residual $\mathrm{DOC}_{\mathrm{P}}$ concentrations also between dosages 0.120 and $0.135 \mathrm{mmol} \mathrm{l}^{-1}\left(80\right.$ and $\left.90 \mathrm{mg} \mathrm{l}^{-1}\right)$, $\left(\mathrm{pH}=6.00-5.80\right.$ and $\left.\mathrm{ANC}_{4.5}=0.32-0.22 \mathrm{mg} \mathrm{l}^{-1}\right)$.

The changes in non-protein organic matter (polysaccharides) concentration with dosage of the destabilisation reagents are also interesting. Its concentration drops to $\mathrm{DOC}_{\mathrm{NP}}=2.54 \mathrm{mg} \mathrm{l}^{-1}$ at a dosage of $0.018 \mathrm{mmol} \mathrm{l}^{-1}\left(10 \mathrm{mg} \mathrm{l}^{-1}\right)$ of ferric sulphate and with increasing dosage it remains unchanged. In contrast, in the case of aluminium sulphate the residual $\mathrm{DOC}_{\mathrm{NP}}$ decreases very slowly with dosage to its lowest residual concentration $\mathrm{DOC}_{\mathrm{NP}}=2.24 \mathrm{mg}$ $\mathrm{I}^{-1}$ at a dosage of $0.231 \mathrm{mmol} \mathrm{l}^{-1}\left(130 \mathrm{mg} \mathrm{l}^{-1}\right)$. It is evident from comparison of the removal of $\mathrm{DOC}_{\mathrm{P}}$ and $\mathrm{DOC}_{\mathrm{NP}}$ that the reduction in $\mathrm{COM}\left(\mathrm{DOC}_{\mathrm{T}}\right)$ is mainly the result of the removal of protein organic matter $\left(\mathrm{DOC}_{\mathrm{P}}\right)$. Low aggregation efficiency of the non-protein organic substances is likely the result of both the electric-neutrality of polysaccharide molecules and the fact that they contain a large quantity of $\mathrm{OH}^{-}$ions owing to which a compact hydration layer is formed around them (Rinaudo, 2001). The low aggregation efficiency of neutral hydrophilic organic matter (polysaccharides) was confirmed also by other researchers (Croue et al., 1993; Kim and Yu, 2004; Pivokonska and Pivokonsky, 2007).

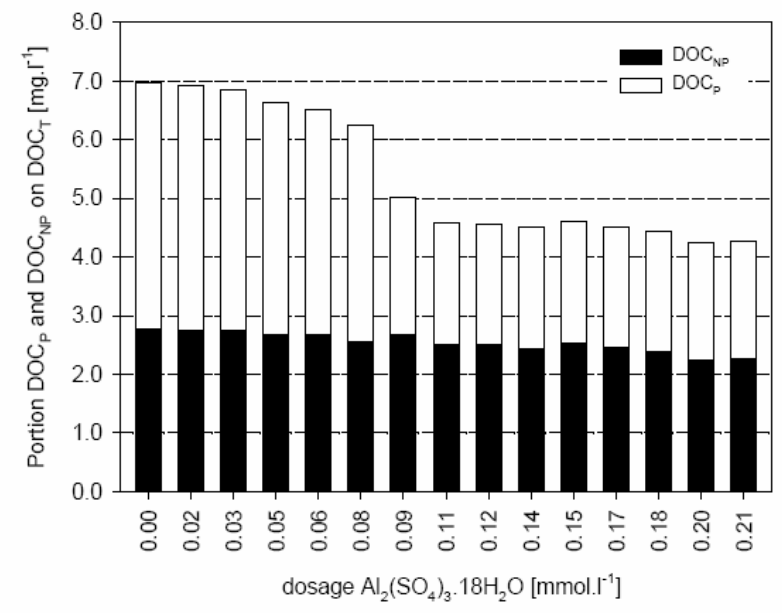

Fig. 7. Dependence of $\mathrm{DOC}_{\mathrm{T}}, \mathrm{DOC}_{\mathrm{NP}}$ and $\mathrm{DOC}_{\mathrm{P}}$ on aluminium sulphate dosage.

Obr. 7. Závislost $\mathrm{DOC}_{\mathrm{T}}, \mathrm{DOC}_{\mathrm{NP}}$ a $\mathrm{DOC}_{\mathrm{P}}$ na dávce síranu hlinitého.

The residual COM concentrations attained with both destabilisation reagents were subjected to fractionation of protein MW. The concentration of proteins identified at a dosage at which the maximum aggregation efficiency is attained, i.e. $\mathrm{D}=0.178$ $\mathrm{mmol} \mathrm{l}^{-1}\left(100 \mathrm{mg} \mathrm{l}^{-1}\right) \mathrm{Fe}_{2}\left(\mathrm{SO}_{4}\right)_{3} 9 \mathrm{H}_{2} \mathrm{O}(\mathrm{Fe}=1.90$ $\left.\mathrm{mg} \mathrm{l}^{-1}, \mathrm{DOC}_{\mathrm{T}}=3.61 \mathrm{mg} \mathrm{l}^{-1}, \mathrm{DOC}_{\mathrm{P}}=1.07 \mathrm{mg} \mathrm{l}^{-1}\right)$ and $\mathrm{D}=0.195 \mathrm{mmol} \mathrm{l}^{-1}\left(130 \mathrm{mg} \mathrm{l}^{-1}\right) \mathrm{Al}_{2}\left(\mathrm{SO}_{4}\right)_{3}$ $18 \mathrm{H}_{2} \mathrm{O}\left(\mathrm{Al}=3.77 \mathrm{mg} \mathrm{l}^{-1}, \mathrm{DOC}_{\mathrm{T}}=4.22 \mathrm{mg} \mathrm{l}^{-1}\right.$, $\left.\mathrm{DOC}_{\mathrm{P}}=2.06 \mathrm{mg} \mathrm{l}^{-1}\right)$ are compared in Tab. 1 . 
$\mathrm{T}$ a b $1 \mathrm{e} 1$. Efficiency of protein aggregation.

$\mathrm{T}$ a b u $1 \mathrm{k}$ a 1 . Účinnost agregace proteinů.

\begin{tabular}{|c|c|c|c|c|c|}
\hline \multirow{2}{*}{$\begin{array}{l}\text { Protein } \\
\text { MW } \\
{[\mathrm{kDa}]}\end{array}$} & \multirow{2}{*}{$\begin{array}{c}\text { Raw water } \\
\text { DOC }_{\mathrm{PI}} \\
{\left[\mathrm{mg} \mathrm{l}^{-1}\right]}\end{array}$} & \multicolumn{2}{|c|}{$\begin{array}{l}\text { Purified water } \\
\mathrm{Fe}_{2}\left(\mathrm{SO}_{4}\right)_{3} 9 \mathrm{H}_{2} \mathrm{O} \\
\left(\mathrm{D}=100 \mathrm{mg} \mathrm{l}^{-1}\right)\end{array}$} & \multicolumn{2}{|c|}{$\begin{array}{c}\text { Purified water } \\
\mathrm{Al}_{2}\left(\mathrm{SO}_{4}\right)_{3} 18 \mathrm{H}_{2} \mathrm{O} \\
\left(\mathrm{D}=130 \mathrm{mg} \mathrm{l}^{-1}\right) \\
\end{array}$} \\
\hline & & $\begin{array}{r}\mathrm{DOC}_{\mathrm{PI}} \\
{\left[\mathrm{mg} \mathrm{l}^{-1}\right]} \\
\end{array}$ & $\begin{array}{c}\alpha \mathrm{DOC}_{\mathrm{PI}} \\
{[-]} \\
\end{array}$ & $\begin{array}{r}\mathrm{DOC}_{\mathrm{PI}} \\
{\left[\mathrm{mg} \mathrm{l}^{-1}\right]} \\
\end{array}$ & $\begin{array}{c}\alpha \mathrm{DOC}_{\mathrm{PI}} \\
{[-]} \\
\end{array}$ \\
\hline 21 & 0.41 & 0.27 & 0.34 & 0.18 & 0.56 \\
\hline 85 & 0.70 & 0 & 1 & 0.57 & 0.19 \\
\hline 234 & 0.66 & 0.21 & 0.68 & 0.53 & 0.20 \\
\hline 359 & 0.95 & 0.59 & 0.38 & 0.78 & 0.18 \\
\hline 470 & 0.41 & 0 & 1 & 0 & 1 \\
\hline$>900$ & 0.99 & 0 & 1 & 0 & 1 \\
\hline Suma & 4.12 & 1.07 & 0.74 & 2.06 & 0.50 \\
\hline
\end{tabular}

The area of the peaks of each identified protein was recalculated from the $\mathrm{DOC}_{\mathrm{P}}$ concentration to a $\mathrm{DOC}_{\mathrm{PI}}$ (DOC concentration of protein identified using molecular weight fractionation) for the determination value of the aggregation efficiency $\alpha \mathrm{DOC}_{\mathrm{PI}}$ (aggregation efficiency of DOC concentration of protein identified using molecular weight fractionation). It is evident from this comparison that no proteins of MW of $470 \mathrm{kDa}$ and higher than $900 \mathrm{kDa}$ are found in the purified water using both destabilisation reagents. Higher efficiency in the removal of high molecular organic matter, which is proven also by other authors (Chin et al., 1994; Chow et al., 1999), is most likely associated with their structure and the presence of dissociated functional groups on their surface.

In the case of ferric sulphate all proteins of MW $=85 \mathrm{kDa}$ are removed. On the contrary, a higher efficiency in the aggregation of proteins of the lowest $\mathrm{MW}=21 \mathrm{kDa}$ is attained with aluminium sulphate. It is also evident from these results, as already discussed above, that a higher total efficiency in the aggregation of proteins is attained with ferric sulphate.

Monitoring of the size-distribution of aggregates formed by the test of aggregation (Hereit et al., 1980; Polasek and Mutl, 1995) offers one of the best method for the interpretation of the results of jar tests. Figs. 8 and 9 show the development of aggregates formed by both destabilisation reagents under the same hydrodynamic conditions. The residual portion of non-aggregated particles $N A$ corresponds to the course of residual $\mathrm{Fe}$ and $\mathrm{Al}$ concentrations. As it is evident from Fig. 8 the lowest $N A=0.10$ portion was attained with ferric sulphate dosages between 0.071 and $0.142 \mathrm{mmol} \mathrm{l}^{-1}$ (40 and $80 \mathrm{mg} \mathrm{l}^{-1}$ ). The highest portion of macro-aggregates $\mathrm{MA}=0.58$ is attained at a dosage of $0.018 \mathrm{mmol} \mathrm{l}^{-1}$ $\left(10 \mathrm{mg} \mathrm{l}^{-1}\right)$ and thereafter it decreases with increasing dosage. As the portion of macro-aggregates decreases the portion of non-aggregated particles gradually increases with increasing dosages. The development of Al-formed aggregates is illustrated in Fig. 9. The lowest portion of $N A=0.16$ is attained with aluminium sulphate dosage between 0.075 and $0.150 \mathrm{mmol}^{-1}$ (50 and $100 \mathrm{mg} \mathrm{l}^{-1}$ ). The highest portion of macro-aggregates $M A$ was formed at a dosage of $0.075 \mathrm{mmol} \mathrm{l}^{-1}\left(50 \mathrm{mg} \mathrm{l}^{-1}\right)$.

Most probably the relatively high portion of macro-aggregates formed during jar test is caused by the fact that under certain circumstances the COM substances may behave like non-ionic and anionic polyelectrolytes, which by means of the resultant adhesion enable formation of large aggregates (Bernhardt et al., 1986, 1989; Hoyer et al., 1987).

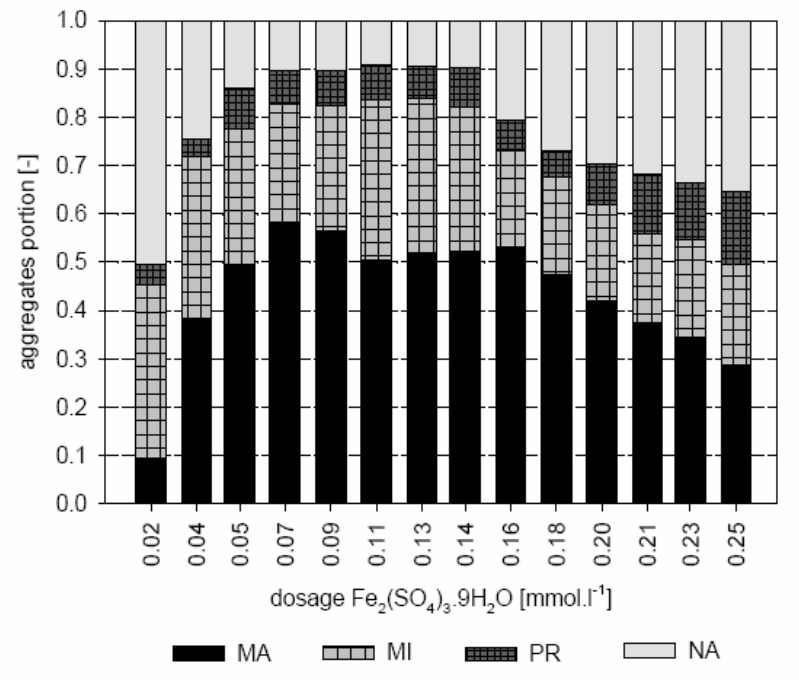

Fig. 8. Dependence of size distribution of formed aggregates on ferric sulphate dosage.

Obr. 8. Závislost velikostní distribuce tvořených agregátů na dávce síranu železitého. 


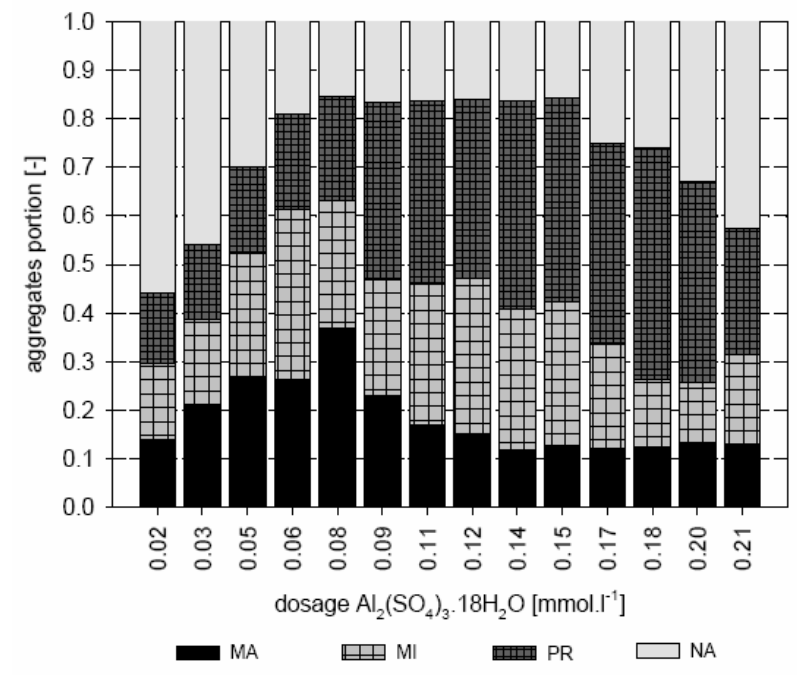

Fig. 9. Dependence of size distribution of formed aggregates on aluminium sulphate dosage.

Obr. 9. Závislost velikostní distribuce tvořených agregátů na dávce síranu hlinitého.

\section{Conclusion}

1. The removal of COM produced by cyanobacteria $M$. aeruginosa is influenced by its composition (content of protein and non-protein organic matter), type and dosage of destabilisation reagent and reaction $\mathrm{pH}$.

2. Proteins of the relative MW of 21, 85, 395, 470 $\mathrm{kDa}$ and higher than $900 \mathrm{kDa}$ are a part of COM of cyanobacteria $M$. aeruginosa. The portion of proteins measured as $\mathrm{DOC}_{\mathrm{P}}$ represents about $59.9 \% \mathrm{DOC}_{\mathrm{T}}$, the total content of organic matter. The removal efficiency of COM is relatively low. It is about $46 \%$ and $41 \%$ in the case of ferric and aluminium sulphate aggregation, respectively.

3. In comparison to other organic matter, mainly polysaccharides, the proteins are removed with higher efficiency. The GPC analyses of the residual COM showed that proteins of a higher MW are aggregated with a higher efficiency.

4. The test of aggregation proved the formation of considerable quantity of the macro-aggregates, mainly during Al-aggregation. Despite this, relatively large residual concentration of $\mathrm{Fe}$ and $\mathrm{Al}$ remains in the purified water.

Acknowledgement. The research project has been funded by the Grant Agency of the Czech Republic under the project No. 103/07/0295 and Institutional Research Plan No. AV0Z20600510. The authors acknowledge the financial assistance on this project.

\section{REFERENCES}

BERNHARDT H., HOYER O., LÜSSE B., SCHELL H., 1989: Influence of algogenic organic substances on flocculation and filtration. A. Hydroch. Hydrobiol., 17, 235-277.

BERNHARDT H., HOYER O., SCHELL H., LÜSSE B., 1985: Reaction mechanisms involved in the influence of algogenic organic matter on flocculation. Z. Wasser-AbwasserForsch., 18, 18-30.

BERNHARDT H., LÜSSE B., HOYER O., 1986: The addition of calcium to reduce the impairment of locculation by algogenic organic matter. Z. Wasser-Abwasser-Forsch., 19, 219-228.

CHIN Y. P., AIKEN G., O'LONGHLIN E., 1994: Molecular weight, polydispersity and spectroscopic properties of aquatic humic substances. Environ. Sci. Tech., 28, 1853$-1858$.

CHOW C. W. K., van LEEUWEN J. A., DRIKAS M., FABRIS R., SPARK K.M., PAGE D.W., 1999: The impact of the character of natural organic matter in conventional treatment with alum. Wat. Sci. Technol., 40, 97-104.

CROUE J. P., LEFEBVRE E., MARTIN B., LEGUBE B., 1993: Removal of dissolved hydrophobic and hydrophilic organic substances during coagulation/flocculation of surface waters. Wat. Sci. Technol., 27, 143-152.

DAWSON R.M.C., ELLIOT D.C., ELLIOT W.H., JONES K.M., 1986: Data for biochemical research. Oxford University Press, New York. 580 pp.

EDWARDS G. A., AMIRTHARAJAH A., 1985: Removing colour caused by humic acids. J. Am. Water Works Assoc., $77,50-57$.

EDZWALD J.K., BECKER W.C., TAMBINI S.J., 1982: Aspect of direct filtration in treatment of low turbidity humic acids waters. Proc. ASCE J. Environ. Eng. Div., 103, 989-1000 .

GREGOR J. E., NOKES C. J., FENTON E., 1997: Optimising natural organic matter removal from low turbidity waters by controlled $\mathrm{pH}$ adjustment of aluminium coagulation. Water Res., 31, 2949-2958.

HEREIT F., MUTL S., VAGNER V., 1980: Direct measurement of floc breakage in flowing suspension. J. Wat. Suppl. Res. Tech. - Aqua, 29, 95-99.

HOYER O., BERNHARDT H., LÜSSE B., 1987: The effect of ozonation on the impairment of flocculation by algogenic organic-matter. Z. Wasser-Abwasser-Forsch., 20, 123-131.

HOYER O., LÜSSE B., BERNHARDT H., 1985: Isolation and characterization of extracellular organic-matter (EOM) from algae. Z. Wasser-Abwasser-Forsch., 18, 76-90.

KIM H.C., YU M.J., 2005: Characterization of natural organic matter in conventional water treatment processes for selection of treatment processes focused on DBPs control. Water Res., 39, 4779-4789.

LÜSSE B., HOYER O., SOEDER C. J., 1985: Mass cultivation of planktonic freshwater algae for the production of extracelular organic-matter (EOM). Z. Wasser- Abwasser-Forsch., $18,67-75$.

PIVOKONSKA L., PIVOKONSKY M., 2007: On the fractionation of natural organic matter during water treatment. J. Hydrol. Hydromech., 55, 4, 253-261.

PIVOKONSKY M., KLOUCEK O., PIVOKONSKA L., 2006: Evaluation of the production, composition and aluminum and iron complexation of algogenic organic matter. Water Res., 40, 3045-3052. 
POLASEK P., MUTL S., 1995: Guidelines to coagulation and flocculation for surface waters, Volume 1: Design Principles for coagulation and flocculation systems. PPA. Marshalltown. $144 \mathrm{pp}$.

POLASEK P., MUTL S., 2005: Optimisation of reaction conditions of particle aggregation in water purification: back to basics. Water SA, 31, 61-72.

RINAUDO M., 2001: Relation between the molecular structure of some polysaccharides and original properties in sol and gel states. Food Hydrocoll., 15, 433-440.

STRUB R., 1961: Ernährubgsphysiologische Untersuchungen an der planktonischen Blaualge Oscillatoria rubescens DC. (In German.) Schweiz. Z. Hydrol., 23, 82-198.

TAKAARA T., SANO D., KONNO H., OMURA T., 2005: Affinity isolation of algal organic matters able to form complex with aluminium coagulant. Water Sci. Technol.: Water Supply, 4, 95-102.

TAKAARA T., SANO D., KONNO H., OMURA T., 2007: Cellular proteins of Microcystic aeruginosa inhibiting coagulation with polyaluminium chloride. Water Res., 41, $1653-1658$.

Received 29. July 2008

Scientific paper accepted 16. October 2008

\section{EFEKT CELULÁRNÍCH ORGANICKÝCH LÁTEK PRODUKOVANÝCH SINICÍ MICROCYSTIS AERUGINOSA NA ÚPRAVU VODY}

Martin Pivokonský, Lenka Pivokonska, Jitka Bäumeltová, Petra Bubáková

Mezi současné významné problémy úpravy povrchové vody patří problematika odstraňování organických látek prírodního původu (NOM), z nichž obzvláště obtížně odstranitelné jsou látky produkované při masovém rozvoji fytoplanktonu, tzv. algae organic matter (AOM). Tyto organické sloučeniny lze obecně rozdělit na látky, které se uvolňují vlivem metabolické činnosti mikroorganismů - extracellular organic matter (EOM) a dále pak na látky uvolňované vlivem jejich masivního odumírání - cellular organic matter (COM). Především pak COM představují pro chemickou technologii úpravy vody, vzhledem $\mathrm{k}$ náhlému zvýšení jejich koncentrací a specifickému složení (zvýšený podíl polysacharidů a některých proteinů), značný problém.

Doposud byla větší pozornost věnována vlivu AOM na průběh úpravy surové vody s obsahem rozdílných znečišt'ujících př́íměsí (hlinitokřemičitany, huminové látky atd.). Z publikovaných prací vyplývá, že působení
EOM na proces destabilizace a agregace znečišt'ujících príměsí se projevuje obdobnými rysy jaké mají neionogenní polymery. Při nízkých koncentracích dochází $\mathrm{k}$ zvyšování účinnosti úpravy vody tvorbou mezičásticových můstků nebo adhezí částic na jejich povrchu. Naopak prí vyšších koncentracích tyto látky brání procesu destabilizace a agregace znečištujujících př́iměsí nárůstem negativního náboje na jejich povrchu, a tak i vzájemnému přiblížení částic. Dále se předpokládá, že některé látky obsažené v AOM, především proteiny, inhibují destabilizační proces tvorbou komplexů s vícemocnými kationty a hydratovanými ionty pomocí koordinačních vazeb. Tvorba těchto komplexů vede $\mathrm{k}$ nárůstu spotřeby destabilizačních činidel a ke snižování účinnosti destabilizace.

Př́spěvek se zabývá problematikou vlivu COM produkovaných sinicí Microcystis aeruginosa na proces chemické úpravy vody destabilizací a následnou agregací znečištujících příměsí. $\mathrm{V}$ průběhu výzkumu v laboratorních podmínkách byla sledována účinnost odstranění nejvýznamnějších složek $\mathrm{COM}$, tj. polysacharidů a proteinů v závislosti na složení, množství a reakčních podmínkách (pH, typ a dávka destabilizačního činidla). COM v surové a upravené vodě byly stanovovány jako DOC, dále byl stanovován podíl polysacharidů a proteinů na celkové koncentraci DOC a detailně bylo složení COM popsáno pomocí relativních molekulových hmotností jejich jednotlivých složek.

$Z$ dosažených výsledků je patrné, že odstranitelnost COM je závislá na jejich složení ale i koncentraci v surové vodě, dále pak také na typu a dávce destabilizačního činidla. Výsledky ukazují, že především podílové frakce COM nižších molekulových hmotností jsou konvenční úpravou vody velmi obtížně odstranitelné a tvoří zásadní podíl zbytkové koncentrace DOC. Účinnost odstranění COM dosahovala při použití síranu železitého hodnot $\alpha_{\mathrm{DOC}}=0,46$ a při použití síranu hlinitého dokonce jen cca $\alpha_{\mathrm{DOC}}=0,41$. Dále bylo zjištěno, že proteiny ve srovnání s ostatními organickými látkami (polysacharidy) jsou odstraňovány s vyšší účinností. Z HPSEC analýzy zbytkových koncentrací proteinů při jednotlivých dávkách destabilizačních činidel je patrné, že účinně jsou odstraňovány především proteiny $\mathrm{s}$ vyšší molekulovou hmotností. Naopak účinnost odstranění polysacharidů je při použití obou destabilizačních činidel velmi nízká $\alpha_{\text {DOCNP }}=0,14-0,22$. 